\title{
EBV in Neck Metastases from Occult Primary Squamous Cell Carcinoma in 57 Years old Female: a Case Report and Review
}

\author{
Abdulaziz Alenazi ${ }^{1}$, Bushra Albalawi ${ }^{2}$ and Jameel Alswahib ${ }^{3}$ \\ ${ }^{1}$ Department of otolaryngology, Imam Abdulrahman Bin Faisal University, Saudi Arabia \\ ${ }^{2}$ College of Medicine, University of Tabuk, Saudi Arabia \\ ${ }^{3}$ Department of otolaryngology, King Saud Medical City (KSMC), Saudi Arabia
}

Submission: December 14, 2017; Published: December 19, 2017

*Corresponding author: Jameel Alswahib, Department of otolaryngology, King Saud Medical City (KSMC), Saudi Arabia, Email: jamil8026@gmail.com

\begin{abstract}
Approximately 1-9\% of all head and neck squamous cell carcinomas are neck metastases from clinically undetectable primary tumors. (EBV) is proven carcinogenic factors that are associated with cell carcinoma and nasopharyngeal carcinoma. In the present case study, we demonstrate the utility of EBV detection in the evaluation of patients with metastases to neck nodes from occult primary carcinomas in order to identify case of NPC. In the present study, we reported a case of 57 years old female patient, known case of HTN admired to KSMC for diagnosis of a pre-existent (6months) painless left neck mass increasing in size associated with hoarseness of voice, for which the primary site was not detected after complete head and neck examination and assessment. Patients was evaluated and treated at the Institute of Otolaryngology, king saud medical city, Riyadh, Saudi Arabia, between November 2016 and December 2016. On the basis of clinical medical history, physical examination, immune histochemical findings, a diagnosis of stage II, Epstein Barr-virus positive, metastasis of nasopharyngeal carcinoma. The primary symptom of unknown primary with NPC is often misdiagnosed, which has been admitted to be suboptimal failure or delay therapy.

Keywords: EBV; Squamous cell carcinoma; Occult primary; Nasopharyngeal carcinoma
\end{abstract}

\section{Introduction}

Carcinoma of unknown primary (CUP) is defined as histologically confirmed metastatic carcinoma in the absence of a detectable primary cancer after a thorough medical history, complete physical examination, and basic laboratory and radiological investigations [1,2]. Even after a full diagnostic workup, the primary site of a CUP remains unknown in $20-50 \%$ of patients. Patients with unknown primary tumor represent $5-10 \%$ of all new cancer patients $[3,4]$. In the United States, it has an incidence of 7-12 cases per 100,000 people per year, corresponding to $2-5 \%$ of all newly diagnosed malignancies [5], in Australia, 18-19 cases [6], and in the Netherlands, 5.3-6.7 cases [7]. According to tumor registry at King Faisal Specialist Hospital and Research Center (KFSH and RC), from 1975 to 2010, there were a total of 1250 cases of CUP, accounting for $1.8 \%$ of all malignancies. CUP is heterogeneous neoplasm that continues to be a diagnostic and therapeutic challenge for physicians. Nasopharyngeal carcinoma affects women more than other head and neck malignancies, and also tends to affect younger age groups compared with most other cancers. Five-year survival rates for NPC range from $30 \%$ to $48 \%$. Nasopharyngeal carcinoma is frequently accompanied by neck lymph node (LN) metastasis, which in many instances is the only manifestation of this disease.
An endoscopic examination or a biopsy of the nasopharynx often fails to detect the primary site because of the submucosal and infiltrative characteristics of NP [8]. This difficulty in diagnosing the primary site may result in suboptimal therapy.

Sometimes NPC can be found early if it causes symptoms that make patients seek medical attention. The symptoms may even seem unrelated to the nasopharynx (for example, a constant feeling of fullness in one ear). But in most people, NPCs may not cause symptoms until they have reached an advanced stage [9]. To our knowledge, the etiologic role of EBV in metastases from UPs has not been specifically and systematically addressed by any study, even if occasional EBV detection has been reported in metastases from undetectable primary in some studies $[10,11]$. Additionally, EBV positivity has been reported in neck metastases without any evident primary tumor at diagnosis, which successively developed overt nasopharyngeal carcinomas [10-18].

\section{Case Assessment}

In this patient, complete head and neck examination was done, evaluated with endoscopy of the upper airways and imaging of the head and neck region [contrast-enhanced magnetic resonance 
imaging and computed tomography (CT)] and chest, pelvis, abdomen(contrast-enhanced CT) were negative for primary tumors. An U/S guided fine-needle aspiration biopsy (FNAB) was then performed Reported malignant Cells Seen. Personal data were collected, there was no environmental risk factors (smoking or alcohol consumption) patients without history of prior malignancy or cutaneous lesions, a comprehensive monolateral neck dissection was performed and gross disease was removed. A definite histologic report revealed High Grade Carcinoma, The histologic report confirmed the presence of metastatic SCC in one or more neck nodes. Immuno histochemistry was showed Tumor cells positive for CK (AE1/AE3) and EBV .We recorded the number and level (according to the classification of the American Academy of Otolaryngology) of positive neck nodes the patients signed informed consent for their participation in the present study. Patient referred to Higher center (King Fasial Specialist Hospital \& Research Center) for further management.

\section{Case Report}

57 years old Saudi female, Known case of HTN and she is on antihypertensive drugs. She was doing well till 6 months, then she developed small swelling on her left side of neck. The swelling gradually increase in size and was not associated with fever, weight loss, difficulty in swallowing or any change in voice. The swelling was slightly tender according to her at that time. For this complain she went to hospital and took medication .After taking medicines she notice slightly decrease in size of swelling. Month later she noticed change of voice along with increase in size of the swelling. With these complaints she again went to hospital from where she was referred to higher center for further workup. She finally presented to otolaryngology department at KSMC where she was admitted urgently for further investigation.

\section{According to examination}

Single swelling about $4.5 \times 5 \mathrm{~cm}$ seen on the left side upper part of the neck, involving upper one third of the neck. It is oval in shape, overlying skin normal. No visible pulsation or redness seen. On palpation swelling is tender, margin well defined, firm in consistency, mobile, overlying skin mobile. Trans illumination negative. Flexible fibre optic examination is done no pathology seen in Nasopharynx, Oropharynx or Hypopharynx. Left vocal cord was paralyzed and was in lateral position.

\section{Hematological investigation}

HB \% 11.3 g\dl, WBC: 18, LYM: 3.32, NEUTRO : 8.65

i. $\quad$ Biochemistry : FBS : $9.1 \mathrm{mmol} / \mathrm{l}$, UREA : $3.7 \mathrm{mmol} / \mathrm{l}, \mathrm{Na}$ : $141 \mathrm{mmol} \backslash \mathrm{l}, \mathrm{K} 4 \mathrm{mmol}$

ii. Radiological : X-Rays - Neck \& chest -A/P \& lateral, CT scan with IV contrast for head \& Neck, chest, abdomen and pelvis was done with unremarkable result

iii. Special investigation: U/S guided FNAC was done Reported malignant Cells. iv. Panendoscopy: done under general anesthesia and multiple biopsies taken from Nasopharynx, base of the tongue, pyriform fossae, valleculae All reported were negative. Finally excisional biopsy was planned and Lt. Modified Radical Neck Dissection done. During surgery mass was seen adherent to Lt. Carotid sheath \& invading it. Mass removed and sent for histopathology.

\section{v. Histopathology :}

a. Tumor cells positive for: CK (AE1/AE3) and EBV .

b. Negative for P63, CK5/6, CK7 , CK20 , Synaptophysin, Chromogranin, S100, HMB45 \& CD45.

c. High Grade Carcinoma.

d. Tumor maximum dimension measures $4 \mathrm{~cm}$.

e. Vascular \& per neural invasion invasion are noted.

f. Tumor Cells reaches the surgical resection margin.

g. Nine out of thirty six lymph nodes are positive for metastatic carcinoma.

Patient referred to Higher center (King Fasial Specialist Hospital $\&$ Research Center) for further management.

a) Tumor cells positive for $\mathrm{CK}(\mathrm{AE} 1 / \mathrm{AE} 3)$ and EBV

b) Negative for P63, CK5/6, CK7, CK20, synaptophysin , Chromogranin, S100, HMB45 and CD 45

\section{vi. Diagnosis :}

a. metastasis NPC, Left Neck mass with level I and II Lymph node

\section{b. High Grade Carcinoma}

c. Tumor maximum Dimension Measures $4 \mathrm{~cm}$

d. Vascular and perineural invasion are noted

e. Tumor cells reaches the surgical Resection margin

f. Nine out of thirty six lymph nodes are positive for metastatic carcinoma

\section{Literature Review}

After extensive evaluation of patients with metastatic neck disease and clinically undetectable primary cancer of the head and neck, the clinician is often faced with the difficult question of subsequent management. Metastatic cancers from unknown primary lesions represent a heterogeneous group that is estimated to account for $5-10 \%$ of all malignancies. Approximately $90 \%$ of these neoplasms are squamous cell carcinomas (SCC), and the remainder includes adenocarcinomas, melanomas, and other rare histologic variants [9-11]. Nevertheless, in approximately 1-9\% of all head and neck malignancies, which are usually characterized by unilateral metastases at level IIa (jugulodigastric), the primary 
SCC remains clinically undetectable (unknown primary tumor, UP) after a thorough and appropriate assessment and rarely becomes apparent on follow-up [12-14].

Notoriously, cancers that arise from mucosal head and neck sites can be etiologically linked with oncogenic viral infections, namely nasopharyngeal carcinoma with the Epstein-Barr virus (EBV) and oropharyngeal SCC with high-risk human papillomavirus (HPV) genotypes [15-18]. EBV infection is typically associated with nonkera- tinizing nasopharyngeal carcinomas (World Health Organization type 2), which clearly have better survival and are markedly more radiosensitive than differentiated cases (World Health Organization type 1) [9-23]. To our knowledge, the etiologic role of EBV in metastases from UPs has not been specifically and systematically addressed by any study, even if occasional EBV detection has been reported in metastases from undetectable primary in some studies [10,11]. Additionally, EBV positivity has been reported in neck metastases without any evident primary tumor at diagnosis, which successively developed overt nasopharyngeal carcinomas $[10,18]$. The evaluation in neck metastatic nodes of both EBV and HPV is therefore rational and has been proposed as a tool in the search for the primary tumor site, with promising preliminary results [19-24].

\section{References}

1. Abbruzzese JL, Abbruzzese MC, Lenzi R, Hess KR, Raber MN (1995) Analysis of a diagnostic strategy for patients with suspected tumors of unknown origin. J Clin Oncol 13(8): 2094-2103.

2. Varadhachary GR, Abbruzzese JL, Lenzi R (2004) Diagnostic strategies for unknown primary cancer. Cancer 100 (9): 1776-1785.

3. Greco FA, Hainsworth JD (2008) Cancer of unknown primary site. In: Vita VD Jr., Hellman S, Rosenberg S, Markoe AM, editors. Cancer: Principles and Practice of Oncology. $8^{\text {th }}$ edn. Lippincott, Philadelphia, USA, pp. 2363-2387.

4. Lembersky BC, Thomas LC (1996) Metastases of unknown primary site. Med Clin North Am 80(1): 153-171.

5. Muir C (1995) Cancer of unknown primary site. Cancer 75: 353-356.

6. Currow D, Thomson W, Lu H (2015) Cancer in New South Wales: Incidence and Mortality Report 2010. Sydney: Cancer Institute NSW, p. 32 .

7. The Netherlands Cancer Registry 2015.

8. Neel HB III (1992) Nasopharyngeal carcinoma: diagnosis, staging, and management. Oncology (Williston Park) 6(2): 87-95.

9. Grau C, Johansen LV, Jakobsen J, Geertsen P, Andersen E, et al. (2000) Cervical lymph node metastases from unknown pri mary tumours. Results from a national survey by the Danish Society for Head and Neck Oncology. Radiother Oncol 55: 121-129.

10. de Braud F, al Sarraf M (1993) Diagnosis and management of squamous cell carcinoma of unknown primary tumor site of the neck. Semin Oncol 20: 273-278.
11. Calabrese L, Jereczek-Fossa BA, Jassem J, A Rocca, R Bruschini, et al. (2005) Diagnosis and management of neck metastases from an unknown primary. Acta Otorhinolaryngol Ital 25: 2-12.

12. Lembersky BC, Thomas LC (1996) Metastases of unknown primary site. Med Clin N Am 80: 153-171.

13. Jereczek-Fossa BA, Jassem J, Orecchia R (2004) Cervical lymph node metastases of squamous cell carcinoma from an unknown primary. Cancer Treat Rev 30: 153-164.

14. Waltonen JD, Ozer E, Hall NC, Schuller DE, Agrawal A (2009) Metastatic carcinoma of the neck of unknown primary origin: evolution and efficacy of the modern workup. Arch Otolaryngol Head Neck Surg 135: 1024-1029.

15. Bouvard V, Baan R, Straif K, Grosse Y, Secretan B, et al. ( 2009) A review of human carcinogens-part B: biological agents. Lancet Oncol 10(4): 321-322.

16. Pathmanathan R, Prasad U, Chandrika G, Sadler R, Flynn K, et al. (1995) Undifferentiated, nonkeratinizing, and squamous cell carcinoma of the nasopharynx. Variants of Epstein-Barr virus-infected neoplasia. Am J Pathol 146(6): 1355-1367.

17. Young LS, Rickinson AB (2004) Epstein-Barr virus: 40 years on. Nat Rev Cancer 4(10): 757-768.

18. Gillison ML, Koch WM, Capone RB, Spafford M, Westra WH, et al. (2000) Evidence for a causal association between human papillomavirus and a subset of head and neck cancers. J Natl Cancer Inst 92(9): 709-720.

19. Khademi B, Mahmoudi J, Monabati A, Maghsoudi B, Ashraf MJ, et al. (2009) Molecular diagnosis of nasopharyngeal carcinoma using detection of Epstein-Barr virus latent membrane protein-1 gene in cervical metastatic lymph nodes. Am J Otolaryngol 30(2): 95-100.

20. Lee WY, Hsiao JR, Jin YT, Tsai ST (2000) Epstein-Barr virus detection in neck metastases by in-situ hybridization in fine-needle aspiration cytologic studies: an aid for differentiating the primary site. Head Neck 22(4): 336-340.

21. Feinmesser R, Miyazaki I, Cheung R, Freeman JL, Noyek AM, et al. (1992) Diagnosis of nasopharyngeal carcinoma by DNA amplification of tissue obtained by fine-needle aspiration. N Engl J Med 326(1): 1721.

22. Strojan P, Ferlito A, Medina JE, Woolgar JA, Rinaldo A et al. (2013) Contemporary management of lymph node metastases from an unknown primary to the neck: I. A review of diagnostic approaches. Head Neck 35(1):123-132.

23. Baldassarri R, Aronberg R, Levi AW, Yarbrough WG, Kowalski D, et al. (2015) Detection and genotype of high-risk human papillomavirus in fine-needle aspirates of patients with metastatic squamous cell carcinoma is helpful in determining tumor origin. Am J Clin Pathol 143(5): 694-700.

24. Hakima L, Adler E, Prystowsky M, Schiff B, Schlecht N et al. (2015) Hybrid Capture 2 human papillomavirus testing of fine needle aspiration cytology of head and neck squamous cell carcinomas. Diagn Cytopathol 43(9): 683-687. 
(C) This work is licensed under Creative BY DOI: $10.19080 /$ GJO.2017.12.555838
Your next submission with Juniper Publishers will reach you the below assets

- Quality Editorial service

- Swift Peer Review

- Reprints availability

- E-prints Service

- Manuscript Podcast for convenient understanding

- Global attainment for your research

- Manuscript accessibility in different formats

( Pdf, E-pub, Full Text, Audio)

- Unceasing customer service

Track the below URL for one-step submission https://juniperpublishers.com/online-submission.php 